\title{
The correlation and influence of intercultural communication in creating social harmonization between ethnicities
}

\author{
Rosy Febriani Daud ${ }^{1 *}$, Agung Prihatmojo ${ }^{2}$ \\ ${ }^{1}$ Communication Studies, Faculty of Law and Social Sciences, Universitas Muhammadiyah \\ Kotabumi \\ ${ }^{2}$ Faculty of Teacher Training and Education, Universitas Muhammadiyah Kotabumi \\ Corresponding author, email: rosydaud@gmail.com
}

\author{
Article History \\ Received: 11/11/2021 \\ Revised: $16 / 12 / 2021$ \\ Accepted: 20/12/2021 \\ Published: $31 / 12 / 2021$
}

\begin{abstract}
Different cultural backgrounds can cause conflict and friction. Individual differences are the cause, differences in understanding and expectations. The impact of the development of the times requires humans to eliminate the group ego for a harmonious relationship between human beings. This is in the diversity of tribes that require the community to live in a harmonious relationship. This research has the title Correlation Regarding the Effect of Intercultural Communication in Creating Inter-Ethnic Harmonization. The aim is to see the extent of the influence of intercultural communication in creating harmonization between the Sumendo and Sundanese ethnic groups in Sindang Marga Village, Tanjung Raja District, North Lampung Regency. The problem formulation of this research is how the influence of intercultural communication in creating harmonization between the Sumendo and Sundanese ethnic groups in Sindang Marga Village, Tanjung Raja District, North Lampung Regency. The method used in this study is the quantitative method. The results of this study were 10 respondents $(20 \%)$ in the high category and 8 respondents in the medium category (16\%), as many as 7 respondents (14\%) in the low category and as many as 5 respondents. (10\%) are in the very low category. Thus it can be concluded that most respondents are in the category of very high intercultural communication influence. Meanwhile, from 50 respondents, 21 people (42\%) answered the question of inter-ethnic social harmonization variables and were in the very high category. A total of 9 respondents $(18 \%)$ were in the high category, as many as 10 respondents $(20 \%)$ were in the medium category, as many as 5 respondents (10\%) were in the low and very low categories. Thus it can be concluded that most respondents are in the category of very high inter-ethnic social harmonization.
\end{abstract}

Keywords: intercultural communication, harmonization, ethnicity

\section{Introduction}

Basically, humans are dependent creatures. Thus, they cannot live independently and definitely need other people to overcome the obstacles that exist in their lives, so that humans are commonly referred to as social beings. The Indonesian nation is famous for its cultural diversity. What is meant by cultural diversity is a necessity that exists on earth. Cultural diversity is also known 
as cultural diversity. The diversity that exists in Indonesia cannot be erased anymore because it has become the hallmark of the Indonesian nation that distinguishes it from other nations on this earth.

Culture is basically the values that arise from the process of interaction between individuals. These values are recognized, either directly or indirectly, as time passes in the interaction. Even sometimes, a value takes place in individuals' subconscious and is passed on to the next generation. In cultural diversity, there must be differences between one culture and another. According to E.B Tylor, culture is a complex whole, including knowledge, values, beliefs, morals, laws, customs, and other capabilities and habits acquired by humans as members of society (Rachmat, 2014). Therefore, different cultures mean different belief systems, values, norms and attitudes. Differences in cultural backgrounds can sometimes cause friction.

The diversity of cultures in Indonesia becomes a cultural harmonization that can be seen from the community's mutual tolerance for cultural differences and even mindsets. Race, ethnicity, religion, social background, education, skin color, and unavoidable realities. As social beings, humans do not only interact with those who have something in common. Especially in today's global era, starting from tools of transportation and communication and information tools to bridge geographical differences (Nasrullah, 2012).

Before this research was conducted, the researchers looked at and compared previous research entitled The Effect of Intercultural Communication on the Harmonized Relationship of the Tanjung Siporkis Village Community, Galang District Deli Serdang Regency. The aim is to see how far the influence of intercultural communication on the harmonious relationship of the people of Tanjung Siporkis Village. This study uses quantitative methods. This method describes the results of research systematically, factually, and carefully and tries to provide an overview of what has to do with research and then analyzes it to find solutions to the problems faced. From the research results that has been done, it can be seen that there is an influence of intercultural communication on the harmonious relationship of the people of Tanjung Siporkis Village, Galang District, Deli Serdang Regency. By increasing the frequency of communication between people, a calm and harmonious atmosphere can be created through mutual respect, respect, and acceptance of differences. So that the diversity of ethnicity, religion, language and social stratification between different communities can be united through a process of social integration.

The people of Tanjung Raja District are multi-ethnic communities, this area is located in North Lampung Regency and not far from the city center. Nevertheless, Tanjung Raja District has several villages with the highest number of villages in North Lampung Regency, namely a total of 19 villages with an area of 33,170 $\mathrm{Ha}$, the population in 2013 was 30,628 people consisting of 15,672 male 
residents and 14,956 female residents. One of the villages used as research locations is Sindang Marga Village and Sri Menanti Village, these two villages are located in the Tanjung Raja Sub-district, North Lampung Regency (Wikiwand, n.d.).

This village was built since the Dutch colonial era and continues to this day and grows into a plural village. The village is plural because it consists of several ethnic groups. The characteristics of this community are in its traditions and culture, besides that the people of Sindang Marga Village and Sri Menanti Village are known to be friendly and able to communicate well in this regard, even though the education level of the people of Sindang Marga Village and Sri Menanti Village is quite low.

In Tanjung Raja District, Sindang Marga Village and Sri Menanti Village consists of a plural society, namely the Semendo ethnicity and the Sundanese ethnicity, what happens is social integration between the two ethnic groups. Social integration is the process of adjusting the different elements in society so that they become one unit. These different elements can include differences in social position, race, ethnicity, religion, language, habits, value systems and norms (Suryawati, 2012). This difference occurs in Sindang Marga and Sri Menanti villages, as evidenced by the existence of assimilation such as the occurrence of marriages between the Semendo ethnic and Sundanese ethnicities and the use of the Semendo language or Sundanese language in the Sindang Marga and Sri Menanti villagers.

Richard Donald Lewis created a cross-cultural model called The Lewis Cross-Cultural Communication model, which is a model that shows how people from different cultures have diversity in the concepts of time and space, distance, silence, and eye contact. In addition, this model explains how their communication style is reflected in the language patterns they use and how they see the truth, as absolute or modified according to the situation and how they judge attitudes and world views. Lewis divides into 3 communication characteristics in a diagram: cross-cultural, linearactive, multi-active, and reactive.(The Lewis Cross-Cultural Communication model in http://bestcareermatch.com/cross-culturalcommunication\#lewis).

In this regard, researchers are interested in knowing how the influence of intercultural communication in creating harmonization between Sumendo and Sundanese ethnicities in Sindang Marga Village and Sri Menanti Village, Tanjung Raja District, North Lampung Regency. This research is important because if there is a pluralistic society, it is vulnerable to friction and conflict. In a plural society that applies intercultural communication, good relations can be established and not mutually exclusive. The purpose of this study was to see how far the influence of intercultural communication in creating harmonization between Sumendo and Sundanese in Sindang Marga and Sri Menanti villages, Tanjung Raja sub-district, North Lampung district. The researcher hopes to 
provide an understanding of the Semendo and Sundanese ethnic communities in Sindang Marga and Sri Menanti villages about the importance of intercultural communication. In addition, the results of this study are expected to provide guidelines for further research and enrich insight into the science of communication, especially intercultural communication.

\section{Method}

In accordance with the purpose of this study to see how far the influence of intercultural communication in creating harmonization between ethnic Sumendo and Sundanese in Sindang Marga village and Sri Menanti village, Tanjung Raja district, North Lampung regency, this study used a survey research method with a quantitative approach. The population in this study were all residents of Sindang Marga village and Sri Menanti village, Tanjung Raja sub-district, North Lampung regency, with a total of 50 people. Because the population was only 50 people, the sampling method used census sampling, where all population members were sampled (Sugiyono, 2011).

The type of survey research describes certain characteristics of a population, whether related to attitudes, behavior, or other social aspects; the variables studied are aligned with the characteristics that are the focus of the survey's attention (Daud, 2019). Because the purpose of the survey is to describe the characteristics of a large number of populations, the sample becomes an important issue in the survey because the sample must be able to represent or reflect the population. The variables of this research are independent variables, namely the variables that cause the occurrence or influence of the independent variables. The independent variable of this research is intercultural communication. The dependent variable is a variable whose value is influenced by the independent variable. So, the dependent variable in this study is social harmonization. The variables measured regarding this perception are divided into two: the independent variable (X), intercultural communication, and the dependent variable (Y), social harmonization.

Sources of data in this study are primary data and secondary data. Primary data is in the form of answers obtained from questionnaires distributed to respondents about the influence of intercultural communication in creating social harmonization between ethnicities. While secondary data, namely research data obtained indirectly through intermediary or supporting media such as references and news in online media related to this research. The first data analysis technique is to analyze the data, which is the frequency distribution, especially the primary data in the form of a single table.

\section{Formula:}




\section{Description:}

$\mathrm{P}=$ Percentage of answers

$\mathrm{F}=$ Frequency of results obtained based on respondents' answers

$\mathrm{N}=$ Total number of respondents

The second step is to determine the influence of the independent variable (intercultural communication) with the dependent variable (social harmonization) using a simple regression equation, then the equation uses the formula:

$\mathrm{Y}=\alpha+\beta \mathrm{X}$

Dimana:

$\mathrm{Y}=$ Dependent Variable (social harmonization)

$\alpha=$ Intersep

$\beta=$ Slope

$\mathrm{X}=$ Independent variable (intercultural communication) Calculations were carried out using SPSS

\section{Discussion}

\section{Intercultural Communication}

The term communication comes from English, namely communication, while the term communication from Latin is communicatus which means sharing or belonging together. According to Lexicographer (language dictionary expert), the word communication refers to an effort that aims to achieve togetherness. The term communication or in English communication comes from the Latin word communicatio and the word communis which means the same. Same here means the same in meaning. Communication is the process of delivering a statement by one person to another through speech, written words, signs or symbols even though they did not know each other before (Hadiono, 2016).

While the notion of culture, which comes from the Sanskrit word Buddhayah as a form of buddhi, which means mind or reason. The English language is Culture, which comes from the Latin word Colere, which means processing, working, or all human power and efforts to change nature. In the general encyclopedia, culture is defined as the entire social heritage that can be seen as the result of works arranged according to a regular order, usually consisting of materials, technical skills, thoughts and ideas, certain habits and values, certain social organizations, and so on (Tasmuji). , 2011). 
Intercultural communication is the process of sharing information, ideas or feelings among those with different cultural backgrounds. The process of sharing information is carried out verbally and in writing, also through body language, personal style or appearance, or the help of other things around it that clarify the message (Liliweri, 2013).

Meanwhile, according to (Sekeon, 2013) intercultural communication is the delivery of messages and message recipients come from different cultures. From the understanding of the meaning of communication and the meaning of culture that has been explained above, it can be concluded that what is meant by intercultural communication is the process of conveying messages, information, ideas or feelings between people of different cultural backgrounds, such as between ethnic groups, values, and values., beliefs, customs, language, race, education, as well as between social classes that have different cultural backgrounds.

Social life has proven that humans on earth cannot live alone. They definitely do social interaction and are always in touch with each other. This interaction will not occur without the communication process. Sometimes interactions between individuals cross cultural boundaries with each other. Having a different culture makes between two communicators must be able to learn how to communicate, culture and cultural values with one another. That means, in intercultural communication, intercultural interaction will never exist if there is no intercultural communication. (Syairi, 2013)

The way we communicate really depends on the culture we believe in: the language, rules, and norms of each of us. In cross-cultural communication, if there are differences in cultural, sociocultural and psycho-cultural values, it is easy to create prejudice against other ethnicities. 


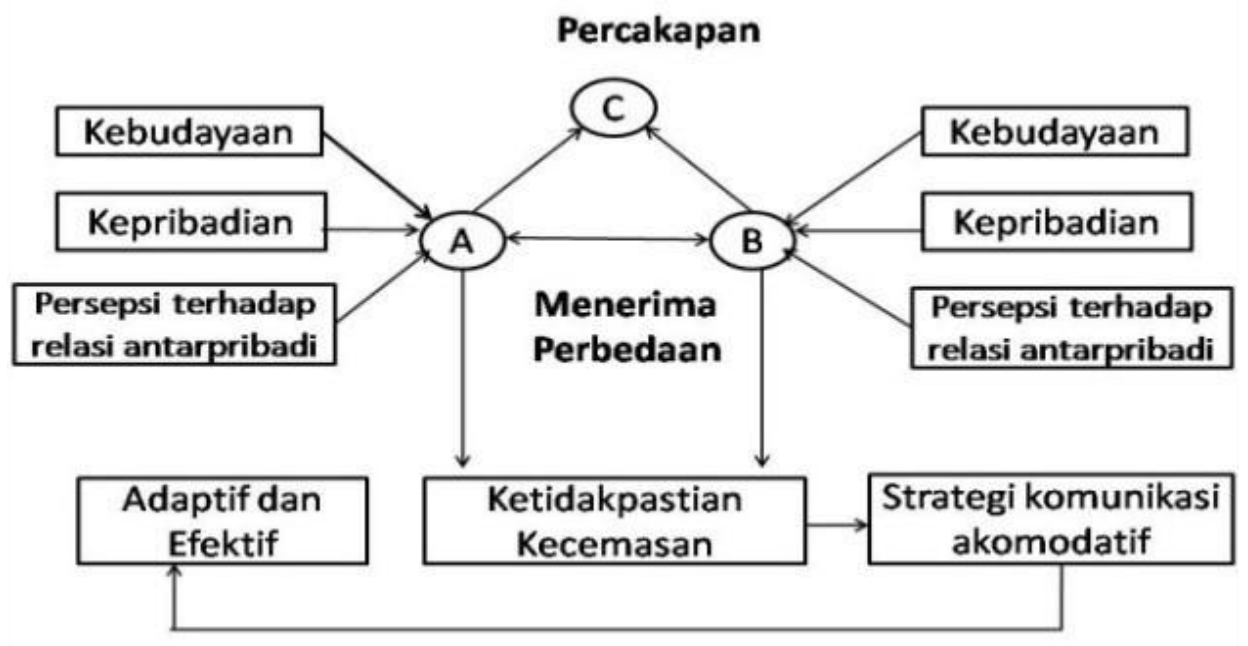

Source: (Liliweri, 2013)

Intercultural communication has three socio-cultural elements that have a significant and direct influence on the meanings we construct in our perceptions, namely;

a. Mark

Values in a culture manifest themselves in the behavior of members of the culture demanded by that culture. This value is called the normative value.

b. Trust / Confidence

In intercultural communication there is no right or wrong as far as it relates to trust. If one believes that the sound of the wind can guide one's behavior to the right path, we cannot say that belief is wrong, we must be able to recognize and deal with that belief if we are to have successful and satisfying communication.

c. Attitude

Beliefs and values contribute to the development of attitudes and values. Attitudes are learned from the cultural context regardless of our environment, the environment will also shape our attitudes, our readiness to respond and finally our behavior (Mulyana, 2011).

\section{Social Harmonization}

According to the Big Indonesian Dictionary, the word harmonization comes from the word harmony tang in Indonesian which means a statement of feelings, actions, ideas, and interests: harmony and harmony. Harmonization is an effort to find harmony, with efforts that allow people to establish harmonious relationships, it will make it easier for people to establish good cooperation in a society that has various cultural differences, in these differences many things can happen, so it is necessary to maintain or strengthen relationships individuals with one another. 
A harmonious relationship will positively impact the community, which can later be used as a capital of togetherness for future generations. Harmonious more completely, namely harmony, compatibility, harmony, with a balance of elements of harmonization and its meaning (Goesniadhie, 2010), including:
a. Some things are excessive tension
b. Align the two plans using their respective parts to form a system
c. The process or effort to realize harmony, suitability, harmony, compatibility, and balance
d. The cooperation between the various factors is such that these factors produce a sublime unity.

\section{Ethnicity}

The term "ethnicity" or "ethnicity" in English is referred to as "ethnicity", "ethnic group" or "ethnic identity". This word is taken from the word "ethnhos" in Greek. By definition, ethnicity refers to a society that together inhabits a certain location with the same language or culture (Vick, 2011).

In various comparative political literatures, ethnicity is used to include various attributes of inherent identity. According to Donald, the concept of ethnicity is a general term that includes a certain group that is distinguished based on skin color, language, and religion which then includes ethnicity (based on culture, especially language), race (based on biological factors), nationality (based on nationality), and caste. (based on the values of social stratification that live in society) (Vick, 2011).

Based on the brief explanation above, ethnicity can be defined as a group of people who inhabit a certain place. A group of people in a certain area has inherent characteristics among each member as a marker of being part of the group. The markers, whether from the similarity of race, ethnicity, religion, culture, customs and so on, function as differentiators from other community or ethnic groups.

\section{Influence of Intercultural Communication}

According to the category of respondents' answers about the level of influence of intercultural communication, analysis of data is grouped into five categories, namely very high, high, medium, low and very low. The grouping of answers is done by looking at all the total scores of respondents' answers in the answer distribution table. 
Based on the distribution table of respondents' answers to variable $\mathrm{X}$, namely the influence of intercultural communication, the highest total score is 75 and the lowest total score is 35 . Then the interval is

$\mathrm{I}=\frac{75-35}{5}=\frac{40}{5}=8$

Thus, the interval of respondents' answers and grouping of categories of respondents' answers are as follows:

$71-79$ : very high category

$62-70$ : high category

53 - 61: medium category

$44-52$ : low category

$35-43$ : very low category

After knowing the respondent's answer, then the data analysis according to the respondent's answer category about the influence of intercultural communication can be seen in the following table:

Table 1. The Effect of Intercultural Communication

\begin{tabular}{lcc}
\hline $\begin{array}{c}\text { Respondent's } \\
\text { Answer } \\
\text { Category }\end{array}$ & Frequency & $\begin{array}{c}\text { Percent } \\
(\mathbf{\%})\end{array}$ \\
\hline Very High & 20 & 40 \\
\hline High & 10 & 20 \\
\hline Currently & 8 & 16 \\
\hline Low & 7 & 14 \\
\hline Very Low & 5 & 10 \\
\hline Total & $\mathbf{5 0}$ & $\mathbf{1 0 0 \%}$ \\
\hline
\end{tabular}

Source: primary data

Based on table 1, it is known that from 50 respondents as many as 20 people (40\%) answered the question of the variable influence of intercultural communication which includes the response of the Semendo ethnic community to the existence of marriage with the Sundanese ethnicity, the public's response to the influence of intercultural communication in the Semendo ethnicity and the Sundanese ethnicity.

The influence of intercultural communication, the response of the Semendo ethnic community to the existence of marriage with the Sundanese ethnicity, the public's response to the influence of intercultural communication in the Semendo ethnic and Sundanese ethnicity. A total of 10 
respondents $(20 \%)$ were in the high category and 8 respondents $(16 \%), 7$ respondents $(14 \%)$ were in the low category and 5 respondents $(10 \%)$ were in the very low category. Thus, it can be concluded that most respondents are in the category of very high intercultural communication influence.

\section{Social Harmonization Between Ethnicities}

The data analysis according to the respondent's answer category regarding social harmonization between ethnicities is grouped into five categories, namely very high, high, medium, low and very low. The grouping of answers is done by looking at all the total scores of respondents' answers in the answer distribution table. Based on the distribution table of respondents' answers to variable $\mathrm{Y}$, namely social harmonization between ethnicities, the highest total score is 90 and the lowest total score is 60 . Then the interval values are:

$$
\mathrm{I}=90-\frac{-60}{5}=\frac{30}{5}=6
$$

Thus, the interval of respondents' answers and grouping of categories of respondents' answers are as follows:

88 - 94: very high category

81 - 87: high category

74 - 80: medium category

$67-73$ : low category

60 - 66: very low category

After knowing the respondent's answer, the data analysis according to the respondent's answer category regarding openness to online media can be seen in the following table:

Table 2. Social Harmonization Between Ethnicities

\begin{tabular}{lcc}
\hline $\begin{array}{c}\text { Kategori } \\
\text { Jawaban } \\
\text { Responden }\end{array}$ & Frekuensi & Persen (\%) \\
\hline Sangat Tinggi & 21 & 42 \\
\hline Tinggi & 9 & 18 \\
\hline Sedang & 10 & 20 \\
\hline Rendah & 5 & 10 \\
\hline Sangat Rendah & 5 & 10 \\
\hline Jumlah & $\mathbf{5 0}$ & $\mathbf{1 0 0 \%}$ \\
\hline
\end{tabular}

Source: primary data

Based on table 2, it is known that out of 50 respondents, 21 people (42\%) answered the question of inter-ethnic social harmonization variables and were in the very high category. A total of 9 respondents (18\%) were in the high category, as many as 10 respondents (20\%) were in the medium 
category, as many as 5 respondents (10\%) were in the low and very low categories. Thus it can be concluded that the majority of respondents are in the category of very high inter-ethnic social harmonization.

\section{Conclusion}

Conclusions based on the results of data analysis in the previous discussion can be concluded as follows:

1. Intercultural communication is in the category of influence that has a very high positive and significant correlation on inter-ethnic harmonization. Indicates the positive effect of the respondent's relationship on inter-ethnic social harmonization. Because a good influence is an influence that is in a very high position.

2. The result of the calculation of the coefficient of determination or the $\mathrm{R} 2$ value of 0.590 is obtained. This means that $26.25 \%$ of the influence of intercultural communication is influenced by social harmonization between ethnicities. While the remaining $6.25 \%$ is influenced by other factors that are not observed.

\section{References}

Daud, R. D. A. (2019). Pengaruh Pemberitaan Media Online terhadap Persepsi Penistaan Agama. $J A S P, 3(2)$

Goesniadhie, K. (2010). Harmonisasi Sistem Hukum: Mewujukan Tata Pemerintahan Yang Baik. Nasa Media

Hadiono. (2016). Komunikasi Antar Budaya (Kajian Tentang Komunikasi Antar Budaya Di Pondok Pesantren Darussalam Blokagung Banyuwangi). Jurnal Pendidikan, Komunikasi Dan Pemikiran Hukum Islam, 8(1), 133-156

Liliweri, A. (2013). Dasar-dasar Komunikasi Antarbudaya. Pustaka Pelajar

Mulyana, D. (2011). Komunikasi Antar Budaya. PT Remaja Rosdakarya

Nasrullah, R. (2012). , Komunikasi Antar Budaya:Di Era Budaya Siber. Kencana

Rakhmat, J. (2014). Komunikasi Antarbudaya Panduan Berkomunikasi Dengan Orang-Orang Berbeda Budaya. Remaja Rosdakarya

Sekeon. (2013). Komunikasi Antar Budaya Pada Mahasiswa Fisip Unsrat Komunikasi Antar Budaya Pada Mahasiswa Fisip Unsrat. Acta Diurna, 2(3)

Sugiyono. (2011). Metode Penelitian Kuantitatif, Kualitatif. Alfabeta

Suryawati, K. dan J. M. (2012). Sosiologi untuk SMA/MA Kelas X. Esis Erlangga 
The Indonesian Journal of Communication Studies, Volume 14/ Nomor : 2/ 2021

Page : 128-139

P-ISSN: 1978-323X, E-ISSN: 2685-529

DOI : http://doi.org/10.31315/ijcs.v14i2.6094

Syairi, K. A. (2013). Pembelajaran Bahasa Dengan Pendekatan Budaya. Dinamika Ilmu, 13(2)

Tasmuji. (2011). IAD-ISD-IBD. IAIN Sunan Ampel Press

Vick, D. dan I. (2011). Ethnic and Identitity Politics. Sage Publications

Wikiwand. (n.d.). Tanjung Raja, Lampung Utara. Wikiwand

The Lewis Cross-Cultural Communication model in http://bestcareermatch.com/crossculturalcommunication\#lewis 